\title{
PERLINDUNGAN HUKUM BAGI PEMBELI DALAM SENGKETA JUAL BELI ONLINE
}

\author{
Aditya Ayu Hakiki, Asri Wijayanti, Rizania Kharisma Sari
}

FH Universitas Muhammadiyah Surabaya

\begin{abstract}
In community disputes often occur online purchase adverse buyers. The purpose of this study was to determine the forms of legal protection and remedies for aggrieved buyers in selling and buying online dispute. This research is normative juridical approach to legislation. Results of the first study is a form of legal protection for the buyer in a dispute over online trading that is the rule of law on the rights and obligations of the seller and the buyer (Article 1473-1519 BW), proof of electronic transactions (Article 5 of Law No. 11 of 2008), right to sue tort (Article 1365 BW) if the aggrieved buyer can file a lawsuit based on their default. Results of the second study are legal remedies which can be done by consumers were harmed in selling and buying online dispute consists of litigation (PN, PT, MA Article 48 of Law No. 8 of 1999 jo. Article 38 of Law No. 11 of 2008) and non-litigation through mediation, conciliation or arbitration (Article 39 of Law No. 11 of 2008). The resulting recommendations are needed socialization of legal protection under the Act ITE.
\end{abstract}

Keywords: seller, buyer, buying and selling online, electronic transactions, Default

\section{A. Pendahuluan}

Jual beli online telah dilakukan

oleh masyarakat. Perkembangan dunia bisnis kini semakin berkembang pesat salah satunya berbisnis dengan menggunakan kecanggihan teknologi melalui media internet atau online. Masyarakat kini sangat senang dan lebih memilih untuk berbelanja melalui media onlinekarena terdapat kemudahan dalam bertransaksi. Terdapat manfaat kelebihan dan kekurangan dari jual beli online. Kelebihannya adalah penjual dan pembeli tidak perlu bertemu secara langsung, pemilihan barang bisa dilakukan dimana saja, penjual tidak memerlukan tempat jual (toko), pemasaran dapat diseluruh dunia. ${ }^{1}$ Kekurangannya adalah kualitas barang tidak sesuai dengan di website, tidak mengetahui lokasi dan identitas penjual, rentan terjadi penipuan. ${ }^{2}$

Masyarakat tidak perlu bertemu secara langsung untuk berbelanja atau membeli suatu barang yang dibutuhkan akan tetapi tidak jarang juga masyarakat mengalami kerugian dalam berbelanja dan melakukan transaksi secara online. Transaksi online yang berbasis internet ini telah diatur dalam Undang-Undang Nomor

1 Waran, Ediko, 2009, Perkembangan Teknologi Komunikasi Online edisi Ke: 3050, Universitas Indonesia, Jakarta.

${ }^{2}$ Ibid. 
11 Tahun 2008 Tentang Informasi dan Transaksi elektronik.

Seperti kasus berikut yakni Wahyu Razbaeni telah dirugikan akibat wanprestasi atas jual beli kamera di salah satu web toko onlinepada tanggal 27 November 2012. ${ }^{3}$ Masrini telah dirugikan akibat wanprestasi atas jual beli karpet di salah satu web online pada tanggal 1 Maret 2016. Calon penumpang pesawat di bandara Soekarno-Hatta yang telah dirugikan akibat wanprestasi atas jual beli tiket pesawat di jasa travel onlinetanggal 24 Desember 2015. ${ }^{5}$ Herdien Dwi Andhika telah dirugikan akibat wanprestasi atas jual beli kamera di situs onlineterkenal pada tanggal 23 September $2015 .^{6}$

Kedudukan penjual dan pembeli dalam penjual dalam jual beli online tidak berada dalam satu tempat yang sama. Penjual dalam jual beli online, kedudukannya dapat sebagai penjual, reseller, atau perantara. Diantara semua penjual pada sistim onlinetidak semuanya sebagai asli penjual. Ada yang menjadi asli

\footnotetext{
${ }^{3}$ http://News.Okezone.Com/Read/2012/11 /30/512/725824/Tergiur-Harga-Murah-MahasiswiTertipu-Toko-Online-Fiktif, diakses 23 Maret 2016 23 Maret 2016

${ }^{4} \mathrm{Http} / / /$ Bangka.Tribunnews.com, diakses ber 2016 ${ }^{5}$ http://Metro.Sindonews.com, 25 DesemArjawinangun, Komaruddin Bagja. "Tertipu Belnaja Online, Lapor Polisi Malah Disuruh Ikhlasin", http://Metro.Sindonews.com, 25 September 2016.
}

penjual ada yang menjadi reseller ada yang menjadi perantara. Reseller adalah penyedia stok barang terlebih dahulu untuk dijual kembali kepada pembeli. Stok barang di dapat dari sebuah produk, dan reseller akan membeli kembali dengan jumlah banyak atau grosir agar mendapat harga murah.

Transaksi online yang dilakukan melalui suatu media elektronik disebut electronic commerce. Para pihaknya tidak harus bertemu secara langsung atau dapat tidak saling mengenal sebelumnya. Electronic commerce transaction adalah transaksi antara penjual dan pembeli untuk menyediakan barang, jasa, atau mengambil alih hak. Kontrak ini dilakukan dengan media elektronik tanpa dihadiri para pihak yang melakukan transaksi.

E-Commerce merupakan metode untuk menjual produk secara onlinemelalui fasilitas internet yang merupakan bisnis paling efektif dewasa ini, tetapi para pihak harus benar-benar memahami dan ahli dalam menggunakan fasilitas internet. ${ }^{7}$

Jual beli adalah salah satu bentuk perjanjian jual beli yang diatur dalam hukum perikatan 1457 - 1540 B.W.. Online adalah bentuk transaksi yang diatur dalam Pasal 1 ayat 2 UU No 11 Tahun 2008
${ }^{7}$ Wawan Muhwan Hariri, 2011, Hukum Perikatan, CV. Pustaka Setia, Bandung. Hlm.337. 
Tentang Informasi dan Transaksi Elektronik serta diatur pula dalam Peraturan Pemerintah Nomor 82 Tahun 2012 Tentang Transaksi Elektronik.

Sengketa jual beli online yang mengakibatkan kerugian terhadap pembeli adalah satu bentuk pelanggaran terhadap pasal 1457 B.W. dan pasal 4 UndangUndang Nomor 8 Tahun 1999.

\section{B. Rumusan Masalah}

Dari uraian diatas muncul permasalahan yaitu:

a. Bagaimana bentuk perlindungan hukum bagi pembeli dalam sengketa jual beli online?

b. Apa upaya hukum bagi pembeli yang dirugikan dalam sengketa jual beli online?

\section{Metode Penelitian}

Penelitian ini adalah penelitian hukum normatif dengan menggunakan pendekatan statute approach, atau suatu pendekatan yang beranjak dari peraturan perundang-undangan yang berlaku di Indonesia yang memecahkan isu hukum yang diajukan sesuai dengan hierarkis dan asas-asas perundang-undangan ${ }^{8}$, serta didasarkan pada peraturan perundang-

\footnotetext{
${ }^{8}$ Peter Mahmud Marzuki, 2005, Penelitian hukum, Kencana Prenada Group, Jakarta. Hlm. 136-137.
}

undangan sebagai sentral kajian dan regulasi yang bersangkutan dengan isu hukum yang ditangani baik secara vertikal maupun horizontal. ${ }^{9}$

\section{Pembahasan}

1. Bentuk Perlindungan Hukum Bagi Pembeli dalam Sengketa Jual Beli Online

$$
\text { Perjanjian jual beli diatur dalam }
$$
pasal 1457-1540 B.W.. Menurut pasal 1457 B.W., jual beli adalah suatu persetujuan yang mengikat pihak penjual berjanji menyerahkan sesuatu barang / benda, dan pihak lain yang bertindak sebagai pembeli mengikat diri berjanji untuk membayar harga. Menurut Salim H.S perjanjian jual beli adalah suatu perjanjian yang dibuat antara pihak penjual dan pihak pembeli. ${ }^{10}$ Di dalam perjanjian itu pihak penjual berkewajiban untuk menyerahkan objek jual beli kepada pembeli dan berhak menerima harga dan pembeli berkewajiban untuk membayar harga dan berhak menerima objek tersebut. $^{11}$

${ }^{9}$ Asri Wjiayanti, 2002, Strategi Penulisan Hukum Normatif, Lubuk Agung, Bandung. Hlm. 71.

${ }^{10}$ Salim H.S, 2003, Hukum Kontrak Teori Dan Teknik Penyusunan Kontrak, Sinar Grafika, Jakarta. Hlm. 49.

${ }^{11}$ Ibid. 
Di dalam perjanjian jual beli terdapat beberapa asas yang mendasari perjanjian jual beli yaitu :

1. Asas kebebasan berkontrak

2. Asas konsensualisme

3. Asas mengikatnya suatu perjanjian

4. Asas itikad baik

5. Asas kepribadian

Di dalam perjanjian ada pula beberapa syarat yang harus dipenuhi sebelum melakukan perjanjian, yaitu :

\section{Sepakat}

2. Cakap

3. Kausa yang halal

4. Suatu hal tertentu

Terdapat pula hak dan kewajiban bagi penjual dan pembeli dalam melakukan perjanjian jual beli, yaitu :

\section{1) Hak dan Kewajiban Penjual}

Hak dari Penjual menerima harga barang yang telah dijualnya dari pihak pembeli sesuai dengan kesepakatan harga antara kedua belah pihak. Sedangkan kewajiban Penjual adalah :

a. Menyerahkan hak milik atas barang yang diperjualbelikan. Di dalam B.W. mengenal tiga jenis benda yaitu benda bergerak, benda tidak bergerak dan benda tidak bertubuh maka penyerahan hak miliknya juga ada tiga macam yang berlaku untuk masing-masing barang tersebut yaitu :

- Benda bergerak

- Benda tidak bergerak

- Penyerahan benda tak bertubuh

b. Menanggung kenikmatan tenteram atas barang tersebut dan menanggung cacat tersembunyi. Pasal 30 sampai dengan Pasal 52 United Nations Convention on Contract for the International Sale of Goods mengatur tentang kewajiban pokok dari penjual yaitu sebagai berikut

- Menyerahkan barang

- Menyerahterimakan dokumen

- Memindahkan hak milik ${ }^{12}$

2) Hak dan Kewajiban Pembeli

Hak dari pembeli adalah menerima barang yang telah dibelinya, baik secara nyata maupun secara yuridis. Kewajiban pembeli untuk membayar harga barang adalah termasuk tindakan pemenuhan prestasi dalam perjanjian jual beli yang telah dibuat oleh para pihak ditempat pembayaran yang telah disepakati kedua belah pihak. Kewajiban pihak pembeli adalah : ${ }^{13}$

a. Membayar harga yang dibelinya sesuai dengan janji yang telah dibuat

12 Salim H.S.,Hukum Kontrak Teori Dan Teknik Penyusunan Kontrak, Sinar Grafika, Jakrta, 2003, Hlm. 56.

${ }^{13}$ Ibid. Hlm. 57. 
b. Memikul biaya yang telah ditimbulkan dalam jual beli, misalnya ongkos kirim.

2. Transaksi Elektronik

E-commerce atau transaksi elektronik telah diatur dalam UndangUndang Republik Indonesia Nomor 11 tahun 2008, selanjutnya disebut dengan UU ITE yang mendefinisikan $e$-commerce sebagai transaski elektronik adalah sebuah perbuatan hukum yang dilakukan dengan menggunakan komputer, jaringan komputer dan/atau media elektronik lainnya (Pasal 1 ayat 2 UU ITE). ${ }^{14}$

Di dalam UU ITE terdapat pula asas-asas hukum informasi dan transaksi elektronik, diatur dalam Pasal 3 UU Nomor 18 Tahun 2008 tentang ITE, yang meliputi asas kepastian hukum, manfaat, kehati-hatian, itikad baik, dan kebebasan memilih teknologi atau netral teknologi.

Yang menjadi obyek e-commerce adalah barang atau jasa yang diperjual belikan oleh penjualkepada setiap orang yang membeli barang dan jasa melalui $e$ commerce. Namun tidak semua barang atau jasa dapat diperjualbelikan dalam $e$ commerce. UU ITE dan UUPK tidak mengatur mengenai syarat-syarat barang atau jasa yang diperbolehkan untuk diperjualbelikan dalam e-commerce,

14 Siswanto Sunarso, 2009, Hukum Informasi Dan Transaksi Elektronik, Rineka Cipta, Jakarta. Hlm. 57. namun dengan melihat ketentuan Pasal 1320 B.W.

UU ITE tidak mengatur mengenai kriteria barang yang boleh diperdagangkan dalam transaksi e-commerce, namun UU ITE mewajibkan penjual untuk menyediakan informasi yang lengkap dan benar berkaitan dengan produk yang ditawarkan (Pasal 9 UU ITE) dan melarang penyebaran berita bohong dan menyesatkan yang mengakibatkan kerugian pembeli dalam transaksi elektronik (Pasal 28 ayat (1) UU ITE).

Dalam UU ITE, dokumen elektronik bisa dijadikan sebagai alat bukti apabila terjadi sengketa antara kedua belah pihak yang telah mengikatkan diri melalui transaksi elektronik. Pada Pasal 5 diarur tentang informasi elektronik dan dokumen elektronik, yang berbunyi :

1. Informasi elektronik dan/ atau dokumen elektronik dan/atau hasil cetakannya merupakan alat bukti hukum yang sah.

2. Infromasi elektronik dan/atau dokumen elektronik dan atau hasil cetakannya sebagaimana dimaksud pada ayat (1) UU ITE merupakan perluasan dari alat bukti yang sah sesuai dengan hukum acar yang berlaku di Indonesia.

3. Informasi elektronik dan/atau dokumen elektronik dinyatakan sah apabila menggunakan system elektronik sesuai 
dengan ketentuan yang diatur dalam undang-undang ini.

4. Ketentuan mengenai informasi elektronik dan/ atau dokumen elektronik sebagaimana dimaksud pada ayat (1) tidak berlaku untuk:

a. Surat yang menurut undang-undang harus dibuat dalam bentuk tertulis; dan

b. Surat berserta dokumennya yang menurut undang-undang harus dibuat dalam bentuk akta notariil atau akta yang dibuat oleh pejabat pembuat akta. ${ }^{15}$

Selain ketentuan yang diuraikan oleh pasal diatas, terdapat ketentuan lain yang diatur dalam pasal 6 UU ITE dan pasal 7 UU ITE bahwa suatu informasi elektronik dan/atau dokumen elektronik dapat digunakan sebagai alasan timbulnya suatu hak. ${ }^{16}$

\section{Jual Beli Melalui Transaksi Elektronik}

Transaksi online adalah transaksi yang dilakukan penjual dan pembeli secara online melalui media internet dan tidak membutuhkan kehadiran para pihak. Pada transaksi jual beli melalui internet, para pihak terkait di dalamnya melakukan hubungan hukum yang dituangkan dalam bentuk perjanjian atau kontrak yang

\footnotetext{
${ }^{15}$ Ibid. Hlm. 48.

${ }^{16}$ Ibid, Hal.51.
}

dilakukan secara elektronik dan sesuai dengan Pasal 1 angka 17 UU UndangUndang Nomor 11 Tahun 2008 Tentang Informasi dan Transaksi Elektronik (ITE) disebut sebagai kontrak elektronik yakni perjanjian yang dimuat dalam dokumen elektronik atau media elektronik lainnya. Perjanjian E-commerce dikenal dua pelaku yaitu merchant/penjualyang melakukan penjualan dan buyer/costumer/pembeli yang berperan sebagai pembeli.

Proses transaksi yang biasanya dilakukan antara penjual onlines hop dan pembeli adalah sebagai berikut :

1. Transfer Antar Bank

Jenis transaksi ini memudahkan proses konfirmasi karena dana bisa dengan cepat di cek oleh penjual setelah menerima bukti transfer.

\section{COD (Cash on delivery)}

Pada sistem transaksi macam ini adalah transaski yang mempertemukan antara penjual dan pembeli.

\section{Rekening Bersama}

Cara pembayaran ini sedikit berbeda dengan proses pembayaran melalui transfer bank. Jika dalam transfer bank, pihak ketiga nya adalah bank, sedangkan dengan sistem Rekber yang menjadi pihak ketiga adalah lembaga pembayaran yang telah dipercaya baik oleh pihak penjual 


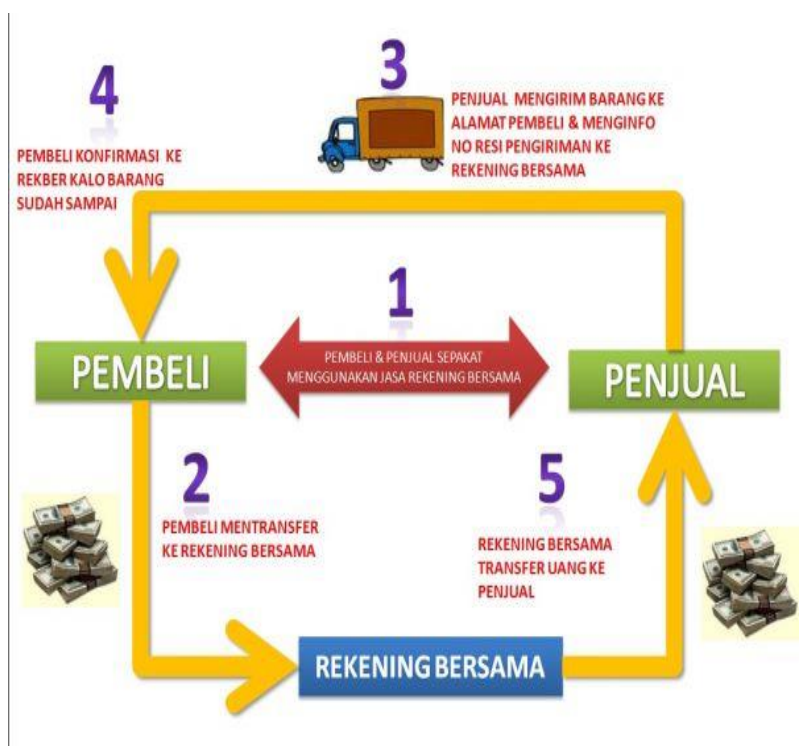

maupun pembeli. ${ }^{17}$ Skema proses transaksi menggunakan rekening bersama $:^{18}$

4. Hubungan Hukum antara Penjual dan Pembeli

Transaksi yang dilakukan dalam forum jual beli online akan menimbulkan hubungan hukum yang melibatkan setidaknya tiga pihak yaitu pembeli (buyer), penjual (seller), dan situs online (facebook, instagram, kaskus dll) . Namun dari ketiga pihak tersebut, pihak-pihak yang terlibat secara langsung adalah pembeli (buyer), penjual (seller). Situs belanja online sendiri tidak terlibat secara langsung dalam transaksi yang dilakukan antara pembeli dan penjual oleh sebab itu segala akibat yang timbul dari transaksi

\footnotetext{
${ }^{17}$ Rekber (2012), Wadah Diskusi Pengetahuan Tentang Rekening Bersama http://www.google.com, Diakses Pada Tanggal 3 July 2016

18 http://www.aditya-web.com (Ilustrasi Rekening Bersama)
}

online, tidak bertanggung jawab karena tokopedia, bukalapak, facebook, instagram dll sebab pada hanya sebagai media dalam menjalankan usaha yang dilakukan oleh penjual.

Apabila para pihak menggunakan transaksi melalui rekening bersama akan menimbulkan hubungan hukum bagi penjual (seller) dengan pembeli (buyer), penjual (seller) dengan rekening bersama, dan pembeli (buyer) dengan rekening bersama. Ketikan penjual dan pembeli sepakat untuk menggunakan jasa rekening bersama, maka pihak jasa rekening bersama berhak mendapatkan biaya (fee) atas jasa yang mereka berikan kepada pengguna jasa rekening bersama. biaya (fee) ditanggung berdasarkan kesepakatan antara penjual dan pembeli, akan tetapi pada umumnya yang menanggung biaya (fee) jasa rekening bersama adalah pembeli.

5. Permasalahan yang timbul dalam jual beli melalui online

a. Keabsahan Perjanjian dalam transaksi jual beli elektronik

Di dalam Pasal 1320 B.W. adanya 4 syarat sahnya suatu perjanjian yaitu : kesepakatan antara kedua belah pihak untuk mengikatkan diri, kecakapan untuk membuat perjanjian, obyek tertentu dan suatu sebab yang halal. 
$E$-commerce merupakan metode dagang modern yang tidak mempertemukan penjual dan pembeli, maka untuk terjadinya suatu kesepakatan sulit untuk diketahui dengan jelas kapan kesepakatan antara kedua belah pihak itu terjadi.

Selain itu mengenai kecakapan kedua belah pihak juga dipertanyakan karena antara penjual dan pembeli tidak bertemu secara langsung maka tidak dapat diketahui dengan jelas kedua belah pihak tersebut cakap atau tidak menurut UndangUndang.

Mengenai suatu sebab yang halal juga menjadi permasalahan dalam transaksi jual beli melalui internet. Sebab yang halal dalam Undang-Undang adalah tidak melanggar kesusilaan dan ketertiban umum.

b. Keamanan dalam bertransaksi

Masalah keamanan yang dipermasalahkan dalam aspek ini adalah masalah keabsahan pelaku transaksi dan masalah keaslian pesan agar bisa dijadikan barang bukti. ${ }^{19}$

c. Keberadaan penjual dan oembeli yang tidak jelas

Mengingat adanya transaksi yang dilakukan dalam dunia maya, sehingga

19 Abdul Halim Barkatullah, et.al, 2005, Bisnis E-Commerce Studi Sistem Keamanan Dan Hukum Di Indonesia, Pustaka Pelajar, Yogyakarta. dapat kemungkinan seperti pihak yang melakukan transaksi mungkin saja pihak yang secara hukum tidak diperkenankan melakukan tindakan hukum.

d. Wanprestasi

Bentuk-bentuk dari pada wanprestasi yang dilakukan oleh penjual antara lain:

- Tidak Melakukan Apa yang Telah Disanggupi

Dalam penelitian ini, peneliti sering kali menemukan atau bahkan mengalami itikad yang tidak baik dari penjual onlineshop. Penjual seringkali mengabaikan kewajibannya sebagai penjual sehingga merugikan pembeli.

Setelah melakukan transaksi yang telah disepakati para pihak dan penjual sudah menerima haknya, penjual menghilang dan susah untuk dihubungi kembali sedangkan pembeli tidak puas dengan barang sudah dijanjian oleh penjual karena barang tidak sesuai dengan yang diperjanjikan sebelum melakukan transaksi.

- Melaksanakan Apa Yang Dijanjikan Tetapi Terlambat

Bentuk kerugian seperti ini sebenarnya tidak jauh berbeda dengan bentuk kerugian pada huruf "a". Jika barang yang dipesan datang terlambat, tetapi tetap dapat dipergunakan, hal ini 
dapat digolongkan sebagai prestasi yang terlambat.

Sebaliknya, jika prestasinya tidak dapat digunakan lagi, digolongkan sebagai tidak melaksanakan apa yang telah diperjanjikan.

6. Upaya Hukum Bagi Pembeli Dalam Sengketa Jual Beli Online

Upaya hukum yang dapat ditempuh bagi pembeli dalam sengketa jual beli online adalah melalui dua jalur yaitu jalur litigasi dan jalur non litigasi. Jalur Litigasi atau melalui proses pengadilan, pembeli atau pihak yang dirugikan dapat mengajukan gugatan ke pengadilan sesuai dengan aturan Pasal 38 ayat 1 UU ITE sedangkan jalur non litigsi atau ADR, pembeli dapat menyelesaikan sengketa diluar pengadilan yaitu dengan proses mediasi, konsiliasi, negoisasi atau arbitrase yang diatur dalam pasal 39 ayat 2 UU ITE. Berikut adalah tabel penyelesaian sengketa antara jalur litigasi dan non litigasi:

Tabel 1. Penyelesaian Sengketa Bagi Pembeli Jual Beli Online

\begin{tabular}{|c|c|c|c|}
\hline Keterangan & Mediasi & Konsiliasi & Arbitrase \\
\hline Proses & Non formal & Non formal & Non formal \\
\hline Jangka Waktu & Cepat & Cepat & Cepat \\
\hline Sifat & $\begin{array}{l}\text { Mediator dan para } \\
\text { pihak bersengketa }\end{array}$ & $\begin{array}{l}\text { Konsiliator dan para } \\
\text { pihak bersengketa }\end{array}$ & Arbiter dan para pihak bersengketa \\
\hline Biaya & $\begin{array}{l}\text { Ditanggung } \\
\text { bersama atau } \\
\text { kesepakatan para } \\
\text { pihak }\end{array}$ & $\begin{array}{l}\text { Ditanggung bersama } \\
\text { atau kesepakatan para } \\
\text { pihak }\end{array}$ & $\begin{array}{ll}\text { - } & \text { Ditentukan oleh arbiter } \\
\text { - } & \text { Biaya dihitung berdasarkan nilai } \\
\text { perkara (Pasal } 36 \text { Prosedur Arbitrase } \\
\text { BANI) }\end{array}$ \\
\hline Putusan & $\begin{array}{l}\text { Tidak mengikat } \\
\text { (apabila gagal } \\
\text { mencapai } \\
\text { kesepakatan, para } \\
\text { pihak dapat } \\
\text { menempuh upaya } \\
\text { gugatan di } \\
\text { pengadilan atau } \\
\text { arbitrase }\end{array}$ & $\begin{array}{l}\text { Tidak mengikat (apabila } \\
\text { gagal mencapai } \\
\text { kesepakatan, para pihak } \\
\text { dapat menempuh upaya } \\
\text { gugatan di pengadilan } \\
\text { atau arbitrase }\end{array}$ & $\begin{array}{ll}\text { - } & \text { Final } \\
\text { - } & \text { Mempunyai kekuatan hukum tetap } \\
\text { - } & \text { Mengikat para pihak }\end{array}$ \\
\hline
\end{tabular}




\begin{tabular}{|l|l|l|l|}
\hline $\begin{array}{l}\text { Pengambil } \\
\text { Keputusan }\end{array}$ & $\begin{array}{l}\text { Para pihak dengan } \\
\text { fasilitas mediator }\end{array}$ & $\begin{array}{l}\text { Para pihak dengan } \\
\text { fasilitas konsiliator }\end{array}$ & Arbiter \\
\hline
\end{tabular}

\section{Penutup}

Bentuk perlindungan hukum terhadap pembeli dalam sengketa jual beli onlinediatur dalam B.W. jo UU No 11 Tahun 2008 jo. PP No 82 Tahun 2012 jo. B.W.. UU No 8 Tahun 1999 mengatur tentang wanprestasi (Pasal 1243 B.W.) UU No 11 Tahun 2008 mengatur tentang dokumen elektronik sebagai alat bukti (Pasal 5 UU ITE). PP No 82 Tahun 2012 mengatur tentang sahnya kontrak elektronik (Pasal 47 PP No 82 Tahun 2012).

Upaya hukum terhadap pembeli yang dirugikan dalam sengketa jual beli onlineterdiri atas litigasi dan non litigasi. Upaya hukum secara litigasi adalah mengajukan gugatan ke Pengadilan Negeri, banding ke Pengadilan Tinggi, kasasi ke Mahkamah Agung dan Upaya hukum peninjauan kembali ke Mahkamah Agung (Pasal 38 UU ITE)). Upaya hukum non litigasi terdiri atas Mediasi, Konsiliasi, dan Arbitrase (Pasal 39 UU ITE)

\section{Daftar Pustaka}

Buku

Abdul Aziz Hakim, 2011, Negara Hukum dan Demokrasi Di Indonesia,
Penerbit Pustaka Pelajar, Celeban Timur Yogyakarta.

Abdul Halim Barkatullah, et.al, 2005, Bisnis E-Commerce Studi sistem keamanan dan hukum di Indonesia, Pustaka Pelajar, Yogyakarta.

Agus Yudha Hernoko, 2010, Hukum Perjanjian Asas Proporsionalitas Dalam Kontrak Komersial, cetakan k-1, Kencana, Jakarta.

Ahmadi Miru, 2007, Hukum Kontrak dan Perancangan Kontrak, PT Raja Grafindo Persada, Jakarta.

Az Nasution, 2001, Hukum Perlindungan Konsumen Suatu Pengantar, Diadit Media, Jakrta.

C.S.T. Kansil, 2000, Hukum Tata Negara Republik Indonesia, PT Rineka Cipta, Jakarta.

--------, 2010, Perbandingan Hukum Administrasi Negara, Rineka Cipta, Jakarta.

Celine Tri Siwi Kristiyantu, 2008, Hukum Perlindungan Konsumen (cet. ke-1), Sinar Grafika, Jakarta.

Kurniawan, 2011, Hukum Perlindungan Konsumen, UB Press, Malang. 
Lia Sautunninda, 2008, Jual Beli melalui Internet (E-Commerce) kajian menurut buku III KUH Perdata dan Undang-Undang informasi dan Elektronik, Fakultas Hukum Universitas Syiah Kuala, Kuala Lumpur.

M. Arsyad Sanusi, 2005, Hukum Dan

Teknologi Informasi (cet. ke-3), Tim Kemas Buku, Jakarta.

Marzuki Peter Mahmud, 2011, Penelitian Hukum (cet. ke-7), Prenadamedia, Jakarta.

Muladi, 2005, Hak Asasi Manusia Hakekat, Konsep, \& Implikasinya dalam Perspektif Hukum dan Masyarakat, Cetakan k-1, Refika Aditama, Bandung.

Rachmadi Usman, 2003, Pilihan Penyelesaian Sengketa Di Luar Pengadilan, PT Citra Aditya Bhakti, Bandung.

Radito Resa, 2014, Aspek Hukum Transaksi Elektronik Perikatan, Pembuktian, Penyelesaian Sengketa, (Cet. ke-1), Graha Ilmu, Jogjakarta.
Salim H.S, 2003, Hukum Kontrak Teori dan Teknik Penyusunan Kontrak, Sinar Grafika, Jakarta.

2003, Hukum Kontrak Teori dan Teknik Penyusunan Kontrak, Sinar Grafika, Jakarta.

Setiono, 2004, Rule of Law (Supremasi Hukum), Magister Ilmu Hukum Program Pascasarjana Universitas Sebelas Maret, Surakarta.

Shidarta, 2000, Hukum Perlindungan Konsumen, Grasindo, Jakarta.

Siswanto Sunarso, 2009, Hukum Informasi Dan Transaksi Elektronik, Rineka Cipta, Jakarta.

Suyud Margono, 2004, ADR \& ARBITRASE Proses Pelembagaan dan Aspek Hukum (cet ke-2), Ghalia Indonesia, Bogor.

Waran, Ediko, 2009, Perkembangan Teknologi Komunikasi Online, Edisi Ke: 3050, Universitas Indonesia, Jakarta.

Wawan Muhwan Hariri, 2011, Hukum Perikatan, CV. Pustaka Setia, Bandung. 
Daftar Perundang-Undangan

Burgerlijk Wetboek (B.W.)

Undang-Undang Republik Indonesia

Nomor 8 Tahun 1999 Tentang

Perlindungan Konsumen (LNRI

Tahun 1999 Nomor 42, TLNRI

Tahun 1999 Nomor 3821)

Undang-Undang Nomor 30 Tahun 1999

Tentang Arbitrase dan Alternatif

Penyelesaian Sengketa (LNRI Tahun

1999 Nomor 138, TLNRI Nomor

Tahun 1999 3872)

Undang-Undang Republik Indonesia

Nomor 11 Tahun 2008 Tentang

Informasi dan Transaksi Elektronik

(LNRI Tahun 2008 Nomor 58,

TLNRI Tahun 2008 Nomor 4843)

Peraturan Pemerintah Nomor 82 Tahun

2012 Tentang Transaksi Elektronik

(LNRI Tahun 2012 Nomor 189,

TLNRI Nomor 5348)

Website

http://news.okezone.com/read/2012/11/30/

512/725824/tergiur-harga-murah-

mahasiswi-tertipu-toko-online-fiktif,

diakses tanggl 23 Maret 2016 http://bangka.tribunnews.com, diakses tanggal 23 Maret 2016

http://metro.sindonews.com, Irawan, Deny. "Puluhan Penumpang Bandara Soetta Tertipu Travel Online”, metro.sindonews.com, 25 Desember 2015, diakses tanggal 23 Maret 2016

http://metro.sindonews.com,

Arjawinangun, Komaruddin Bagja. "Tertipu Belnaja Online, Lapor Polisi Malah Disuruh Ikhlasin”, metro.sindonews.com, 25 September 2015, diakses tanggal 23 Maret 2016

Soemali, Hubungan Antara Konsumen dan Produsen, <www.soemali.dosen.nar otama.ac.id>, diakses pada 10 April 2016

Kamus

Henry Campbell Black, Black's Law Dicitionary, West Group, St. Paul, 1999 